\title{
Erratum to: Elevated levels of kappa free light chains in CSF support the diagnosis of multiple sclerosis
}

Stefan Presslauer - Dejan Milosavljevic •

Thomas Brücke $\cdot$ Peter Bayer $\cdot$ Wolfgang Hübl

Published online: 23 October 2009

(C) Springer-Verlag 2009

Erratum to: J Neurol (2008) 255:1508-1514

DOI 10.1007/s00415-008-0954-z

Author's name was published with errors. The correct author name is given here:

Wolfgang Hübl

Dept. of Laboratory Medicine

Wilhelminenspital, Vienna

The online version of the original article can be found under doi:10.1007/s00415-008-0954-z.

S. Presslauer $(\bowtie) \cdot T$. Brücke

Dept. of Neurology, Wilhelminenspital, Montleartstrasse 37,

1160 Vienna, Austria

e-mail: stefan.presslauer@wienkav.at

D. Milosavljevic $\cdot$ P. Bayer · W. Hübl

Dept. of Laboratory Medicine, Wilhelminenspital, Vienna,

Austria 